\title{
Research and analysis of energy management in ceramic industry
}

\author{
Ming Gong ${ }^{1}$, Guangtao $\mathrm{Li}^{2}{ }^{*}$, Kejing $\mathrm{Li}^{3}$, Kaifang Wang ${ }^{3}$ \\ ${ }^{1}$ Quality Supervision and Inspection of Building and Sanitary Ceramics of Jiangxi Province, Gao An 330800, China \\ ${ }^{2}$ Xi' an JARN Industrial Co.,Ltd Gazelle Valley Pioneer Park,No.69 High-Tech District ,Xi'an city, ShaanXi Province ,China, \\ Code: 710000 \\ ${ }^{3}$ China Building Material Test \& Certification Group (Shaanxi) Co. Ltd, Xi’an, Shaanxi, 710049, China
}

\begin{abstract}
This article mainly researches and analyzes the relevant standards of the energy management system of the ceramic industry at home and abroad, the content of the energy management system and the status quo of the industry's energy management, and elaborates the necessity and urgency of the implementation of energy management standardization in the ceramic industry.
\end{abstract}

\section{Introduction}

The ceramic industry with high energy consumption is one of the key industries for energy saving and emission reduction in my country. The current ceramic industry is in a period of adjustment of development mode. Lowcarbon, green and sustainable development are the main keynotes of the industry in the future. Energy management is a key link in realizing the low-carbon development of enterprises, which directly determines whether enterprises can achieve sustainable development[1].

In 2015, the Energy Conservation and Comprehensive Utilization Department of the Ministry of Industry and Information Technology issued the "Notice on Printing and Distributing the Implementation Plan for the Construction of Energy Management Centers for Enterprises in the Steel, Petroleum and Chemical, Building Materials[2], Non-ferrous Metals, and Light Industry Industries", requiring the implementation of the "Energy Conservation Law" and the improvement of corporate energy management System, strengthen government energy-saving supervision methods, and improve enterprise energy management level. Among them, the "Building Material Enterprise Energy Management Center Construction Implementation Plan" clarifies the basic requirements, construction content, and acceptance standards for the construction of industry energy management centers.

In June 2016, the China Building Materials Federation issued the "Thirteenth Five-Year Science and Technology Development Plan for the Building Materials Industry", which proposed that "the energy consumption of the industrial added value of enterprises above designated size should be reduced by $20 \%$ compared with the "Twelfth Five-Year" period".
The "Thirteenth Five-Year Development Guidance for the Building Ceramics and Sanitary Ware Industry" compiled by the China Building and Sanitary Ceramics Association pointed out that "Develop green strategies, green standards, and establish a green evaluation system. Optimize internal industrial design, promote industrial integration in the park, and achieve resource efficiency Recycling. Strengthen energy management, establish an energy measurement management system, and actively carry out cleaner production audits"[4].

The above national ministries or industry plans all pointed out that ceramic industrialization should develop in the direction of green, ecological, and energy-saving. The introduction of national standards for the implementation of energy management system in the ceramic industry will improve the energy efficiency, energy conservation and emission reduction of my country's ceramic industry. Green development is of great significance.

\section{Analysis of product quality spot check}

Relevant countries in the world have formulated and implemented national standards for energy management systems, such as the "Energy Management Guidelines" formulated by the UK Energy Efficiency Office for building energy management, the MSE2000 "Energy Management System" developed by the American National Standards Institute (ANSI), and the Swedish Standards Institute The "Energy Management System Description" formulated, the "Energy Management System Requirements and Guidelines" formulated by the National Standards Institute of Ireland (NSAI), the "Energy Management Code" issued by the Danish Standards Association, etc. In addition, South Korea has also issued corresponding national standards[5], and Germany and the Netherlands have also formulated 
corresponding energy management system specifications. In addition, in 2010, the European Committee for Standardization (CEN) developed and issued the EU standard (EN 16001) required by the energy management system.

The domestic national standard GB/T 23331-2009 "Energy Management System Requirements" was promulgated on March 11, 2009, and officially implemented on November 1, 2009. On October 9, 2009, the National Certification and Accreditation Administration issued the "Notice on Carrying out the Pilot Work of Energy Management System Certification", proposing to carry out pilot projects for the construction of energy management systems in ten key industries including building materials and iron and steel from November 1, 2009, The pilot period is two years. The ISO 50001 international standard was officially promulgated and implemented on June 15, 2011. On December 31, 2012, the national standard GB/T 23331-2012 and GB/T 29456-2012 "Energy Management System Implementation Guide" equivalent to ISO 50001 were issued and released in 2013 It was formally implemented on October 1, 2015. Since the national standards of "Energy Management System Requirements" and "Energy Management System Implementation Guide" are applicable to all industries and all organizations, each industry has its own characteristics in the process of establishing an energy management system, so corresponding implementation guidelines are needed as guidance And action guide to make it operable. On December 31, 2020, the national standards GB/T 233312012 and GB/T 29456-2012 "Energy Management System Implementation Guidelines" equivalent to ISO 50001 were released and officially implemented on
October 1, 2013. On March 1, 2020, the national standard GB/T 38706-2020 "Energy Management System Implementation Guide for the Ceramic Industry" was officially released and officially implemented on October $1,2020$.

\section{Energy management system content and status}

The energy management system should cover the organization's internal processes and outsourcing processes related to energy management; management responsibilities: including management commitments, energy policies, roles, responsibilities, and authority requirements; planning: including energy factors, laws and regulations and other requirements, energy management Requirements for benchmarks and benchmarks, energy goals and indicators, energy management plans, etc.; implementation and operation: including requirements for resources, capabilities, training and awareness, information exchange, document control, record control, operation control, etc.; inspection and correction: Including monitoring, measurement and evaluation, compliance evaluation, non-conformity, correction, corrective measures and preventive measures, internal audit and other requirements; management review: including general rules, review input, review output and other requirements. The main energy-consuming equipment for ceramic industry production includes: jaw crusher, roller crusher, ball mill, forming machine, processing conveyor line, elevator, drying chamber, tunnel kiln, shuttle kiln, washing tower, water pump, etc. The detailed information is shown in Table 1.

Table1. Main energy-consuming equipment in the ceramic industry

\begin{tabular}{|c|c|c|c|}
\hline Serial number & Equipment name & power & quantity \\
\hline 1 & Jaw Crusher & $30 \mathrm{kw}$ & 1 \\
\hline 2 & Roll crusher & $30 \mathrm{kw}$ & 1 \\
\hline 3 & Ball mill & $55 \mathrm{kw}$ & 16 \\
\hline 4 & Ball mill & $45 \mathrm{kw}$ & 4 \\
\hline 5 & Ball mill & $22 \mathrm{kw}$ & 2 \\
\hline 6 & Ball mill & $11 \mathrm{kw}$ & 3 \\
\hline 7 & Forming Machine & $20 \mathrm{kw}$ & 1 \\
\hline 8 & Forming Machine & $20 \mathrm{kw}$ & 1 \\
\hline 9 & Forming Machine & $20 \mathrm{kw}$ & 1 \\
\hline 10 & Forming Machine & $10 \mathrm{kw}$ & 1 \\
\hline 11 & Forming Machine & $5 \mathrm{kw}$ & 1 \\
\hline 12 & Forming Machine & $5 \mathrm{kw}$ & 3 \\
\hline 13 & Processing conveyor line & $10 \mathrm{kw}$ & 3 \\
\hline 14 & lift & $3 \mathrm{kw}$ & 33 \\
\hline 15 & Drying room & 1 & 1 \\
\hline
\end{tabular}




\begin{tabular}{|c|c|c|c|}
\hline 16 & Drying room & $/$ & 1 \\
\hline 17 & Drying room & $/$ & 1 \\
\hline 18 & Drying room & $/$ & 1 \\
\hline 19 & Drying room (low pressure fast drainage) & $/$ & 1 \\
\hline 20 & Tunnel kiln & $135 \mathrm{kw} /$ & 1 \\
\hline 21 & Tunnel kiln & $135 \mathrm{kw}$ & 1 \\
\hline 22 & Tunnel kiln & $94.7 \mathrm{kw}$ & 1 \\
\hline 23 & Tunnel kiln & 141.5 & 1 \\
\hline 24 & Shuttle Kiln & $44 \mathrm{kw}$ & 2 \\
\hline 25 & Shuttle Kiln & $22 \mathrm{kw}$ & 10 \\
\hline 26 & Washing tower & $220 \mathrm{kw}$ & 5 \\
\hline 27 & Water pump (submersible sewage) & 5.5 & 10 \\
\hline 28 & Water pump (other) & 7.5 & 11 \\
\hline
\end{tabular}

The main energy measuring instruments produced in the ceramic industry include: watt-hour meters, floor scales, natural gas flow meters, watt-hour meters, natural gas flow meters, water meters, etc. The detailed information is shown in Table 2.

Table2. Main energy measuring instruments in the ceramic industry

\begin{tabular}{|c|c|c|c|c|}
\hline $\begin{array}{c}\text { Serial } \\
\text { number }\end{array}$ & Name & accuracy level & $\begin{array}{c}\text { number to be } \\
\text { allocated }\end{array}$ & number already allocated \\
\hline 1 & Watt-hour meter & 1 & 3 & 3 \\
\hline 2 & Weighbridge & $/$ & $/$ & 2 \\
\hline 3 & $\begin{array}{c}\text { Natural gas flow } \\
\text { meter }\end{array}$ & 1 & 6 & 6 \\
\hline 4 & Watt-hour meter & 2 & 3 & 3 \\
\hline 5 & $\begin{array}{c}\text { Natural gas flow } \\
\text { meter }\end{array}$ & 2 & 1 & 1 \\
\hline 6 & Water meter & 1 & 11 & 11 \\
\hline 7 & Water meter & 2 & 2 & 6 \\
\hline
\end{tabular}

The energy consumption of natural gas, coal, electricity, gasoline and diesel is converted into standard coal to calculate the comprehensive energy consumption.
The energy consumption flow of enterprises is shown in Table 3.

Table3. The flow of energy consumption in the ceramic industry

\begin{tabular}{|c|c|c|c|c|c|c|c|c|c|}
\hline \multicolumn{2}{|c|}{ Items } & $\begin{array}{c}\text { raw } \\
\text { materials }\end{array}$ & $\begin{array}{c}\text { ball } \\
\text { milling }\end{array}$ & drying & firing & manufacturing & packaging & other & total \\
\hline $\begin{array}{c}\text { electricity } \\
(10,000 \\
\mathrm{kWh} / \mathrm{t})\end{array}$ & $\begin{array}{c}\text { Physical } \\
\text { quantity }\end{array}$ & 47 & 455 & 206 & 452 & 371 & 65 & 154 & 1750 \\
\cline { 2 - 11 } & Scalar & 57 & 560 & 254 & 555 & 456 & 80 & 189 & 2151 \\
\hline $\begin{array}{c}\text { natural } \\
\text { gas } \\
\left(\mathrm{M}^{3}\right)\end{array}$ & $\begin{array}{c}\text { Physical } \\
\text { quantity }\end{array}$ & 0 & 20404.5 & 644418.3 & 5773478.8 & 510145.4 & 0 & $163,265.4$ & 7111710 \\
\cline { 2 - 11 } & Scalar & 0 & 27 & 857 & 7679 & 678 & 0 & 217 & 9459 \\
\hline $\begin{array}{c}\text { gasoline } \\
(\mathrm{t})\end{array}$ & $\begin{array}{c}\text { Physical } \\
\text { quantity }\end{array}$ & 0 & 0 & 0 & 0 & 0 & 0 & 10.14 & 10.14 \\
\hline
\end{tabular}




\begin{tabular}{|c|c|c|c|c|c|c|c|c|c|}
\hline & Scalar & 0 & 0 & 0 & 0 & 0 & 0 & l & \\
\hline \multirow{2}{*}{$\begin{array}{l}\text { Diesel } \\
(\mathrm{t})\end{array}$} & $\begin{array}{l}\text { Physical } \\
\text { quantity }\end{array}$ & 15.69 & 0 & 0 & 0 & 0 & 3.34 & 8.36 & 27.39 \\
\hline & Scalar & 22.86 & 0.00 & 0.00 & 0.00 & 0.00 & 4.87 & 12.18 & 39.91 \\
\hline \multirow{2}{*}{$\begin{array}{c}\text { coal } \\
(\mathrm{t})\end{array}$} & $\begin{array}{l}\text { Physical } \\
\text { quantity }\end{array}$ & 0 & 0 & 0 & 0 & 0 & 0 & 0 & 0 \\
\hline & Scalar & 0 & 0 & 0 & 0 & 0 & 0 & 0 & 0 \\
\hline \multicolumn{2}{|c|}{ Total conversion $(\mathrm{t})$} & 80.17 & 586.67 & 1110.72 & 8234.08 & 1134.36 & 84.95 & 418.33 & 11649.29 \\
\hline \multicolumn{2}{|c|}{ The proportion(\%) } & $0.69 \%$ & $5.04 \%$ & $9.53 \%$ & $70.68 \%$ & $9.74 \%$ & $0.73 \%$ & $3.59 \%$ & $100.00 \%$ \\
\hline
\end{tabular}

\section{Conclusion}

In the future, with the rapid development of modern information technology and manufacturing technology integration and innovation, the building ceramics and sanitary ware industry will develop towards integration, intelligence, and flexibility, and realize the integrated innovation of R\&D, design, production and management, innovative research and development, Manufacturing and industrial organization methods to realize the flexibility, agility, digitization, networking and coordination of manufacturing and supply chains.

\section{References}

1. UNIDO. Quality Infrastructure[R], 2006.

2. XIONG Rui LI Xinggang. Battery Internal Temperature Estimation Method through Double Extended Kalman Filtering Algorithm[J].Journal of Mechanical Engineering 56,146-151(2020).

3. Liu Jiankang, Hao Shanghua, Wang Shuhua, Fu Hongya. Data driven technical framework of realtime monitoring and control optimization for $\mathrm{CNC}$ machining production line[J]. Computer Integrated Manufacturing Systems 25, 1875-1884(2019).

4. KorhanKo et al.(2020)Is Support Vector Regression method suitable for predicting rate of penetration. Journal of Petroleum Science and Engineering.Vol 194, pp. 19-24.

5. World Bank. The National Quality Infrastructure [R], 2013. 